\title{
The Observation Of Defects Of School Buildings Over 100 Years Old In Perak
}

\author{
Kartina Alauddin ${ }^{1, a}$, Mohd Fisal Ishakt ${ }^{1}$, Haryati Mohd Isa ${ }^{1}$ and Fariz Mohamad Sohod ${ }^{1}$ \\ ${ }^{1}$ Faculty of Architecture Planning and Surveying, Universiti Teknologi MARA, Cawangan Perak, Seri Iskandar, 32610, Perak, Malaysia
}

\begin{abstract}
Malaysia is blessed with a rich legacy of heritage buildings with unique architectural and historical values. The heritage buildings become a symbol of the national identity of our country. Therefore, heritage buildings, as important monuments should be conserved well to ensure the extension of the building's life span and to make sure continuity functions of the building for future generations. The aim of this study is to analyze the types of defects attached in school buildings over 100 years located in Perak. The data were collected in four different schools aged over 100 years in Perak. The finding of the study highlighted the types of defects which were categorized based on building elements, including external wall, roof, door, ceiling, staircase, column, internal wall, floor and windows. Finding showed that the type of defects occurred in school buildings over 100 years in Perak is the same as the other heritage buildings. This finding can be used by all parties to take serious actions in preventing defects from occurring in buildings over 100 years. This would ensure that buildings' functional life span can be extended for future use.
\end{abstract}

\section{Introduction}

Malaysia is rich with a legacy of historic buildings which showcases outstanding craftsmanship and architectural qualities. These possess impressive historical features and preserve the heritage of workmanship from the past (Suhana et al., 2013). Nowadays, a lot of effort has been made to preserve the historic buildings. According to Malaysia's former Prime Minister, Datuk Seri Abdullah Ahmad Badawi, billions of Ringgit have been spent and wasted in repairing public buildings due to Malaysia's poor maintenance culture (Abdullah, 2007). The lack of proper maintenance works and identification of historic buildings may contribute to the decaying of buildings, thus resulting in decrement in the number of historic buildings. Proper maintenance is important to ensure the extension of the buildings' life span and to make sure continuous functions of the buildings. There are many types of common defects occurred in buildings such as dampness, termite attacks, cracks, loose plasterwork, efflorescence, and blistering of paintwork (Mardziah \& Azree, 2012). The problems related to the defects in heritage school particularly has been highlighted by Zainal and teams in their research. In late 2007, there were many cases which involved component failures of school buildings reported in Malaysia (Zainal, et al., 2009). These incidents happened caused by the age of buildings, environmental conditions, the building functions, and also maintenance work that was carried out on each building. Many heritage buildings still remain in poor condition with signs of serious building defects threatening their survival because legislations related to heritage buildings in the country do not sufficiently address the issue of maintenance and its management in the conservation of heritage buildings. Therefore, this results in poor maintenance management practices which eventually lead to deterioration of the buildings (Arazi et al., 2010). The objective of this paper is to examine the types of defects in the school buildings aged over 100 years old. The observation focuses on the school buildings in Perak. Perak has been selected as this state has many schools which are above 100 years since the occupation of the British in Malaysia. Many of the school buildings are still in use up until now to preserve the schools' identity

\section{Literature review}

Building defects occur in either new buildings or old ones. Defects in new buildings may be caused by noncompliance with the Building Code and published acceptable tolerances and standards. Meanwhile, for the older buildings, or buildings out of warranty period, they may not comply with these standards but must be judged against the standards at the time of construction or refurbishment (Nadia \& Md Azree, 2013). In most cases, the defects usually occur in old buildings are also known as heritage buildings. According to Kamarul et al.,

\footnotetext{
a Kartina Alauddin: karti540@perak.uitm.edu.my
} 
(2008), heritage buildings are an important element in town development which can be seen in some cities in the world. They play an important role in defining the landmark within the urban area as well as generating income and boosting the tourism industry. Examples of historic buildings in Malaysia are mosques, churches, palaces, clock towers, prisons, government offices, residential, schools, railway stations, hotels, forts, and monuments (Abdul Ghafar, 1997). This research focuses on the defects in heritage school buildings in Perak. In fact, nowadays, building defects are becoming an ordinary phenomena in the construction industry, which contributes negative impacts towards the buildings especially school buildings. It includes the building performance, health and safety aspects, and overall environmental conditions as well as teaching and learning processes (Md Azree et al., 2014). Nevertheless, there are a great number of building defects arise and being officially reported by mass media, especially problems with educational buildings (Md Azree et al., 2014).

\subsection{Definitions of Defects and Heritage Buildings}

Mardziah and Md Azree (2012) explain defects as faults on something that detract from perfection, whilst building damage can be seen when any structure, material, equipment, and element of the building are not fully functional. In another study, construction defects can be defined as a failure or shortcoming in the building's function, performance, statutory, or user requirements, and this may occur in its structure, fabric, services, or other facilities (Haryati, 2011). Besides, defects can also be defined as a lack of something necessary for completeness; shortcoming. Pheng and Wee (2001), Chew (2004), and Oleranrewaju et al. (2010) define those defects as a failure or shortcoming with the design in the function, performance, statutory, or user requirements which may affect its structure, fabric, services, or other facilities. Nielsen et al. (2006) claim that the term defects are commonly used to describe a physical defect and process defect. He also stated that when project documentation, a building material, a structure, or part of structure lacks of abilities, whereby it is able to be expected according to the contract, it is regarded as defects. In addition, Shittu et al. (2013) explains that defects are the non-conformity of a component with a standard of specific characteristics that have been stated as per specification.

Heritage buildings can be classified as 'pre-war buildings' due to their year of build, ranging from 1800 to 1948 as stated by Kamarul et al. (2008). Besides, according to Arazi et al. (2010), heritage buildings referred to buildings formed in the past which are of high values in terms of historical and architectural and needs regular care and protection in order to preserve their values; historical, aesthetic, archaeological, spiritual, social, political and economic. In Malaysia, there are many pre-war buildings are also known as heritage buildings. Almost every state in Malaysia has heritage buildings. Idid (2005) claims that the total number of heritage buildings in Malaysia is 20,787 and Penang is the highest on the list with 5,057 heritage buildings meanwhile the lowest is Sabah with 10 heritage buildings only. Table 1 shows in detail about the distribution of heritage buildings in Malaysia.

Table 1. The Distribution of Pre-War Urban Buildings in Malaysia

\begin{tabular}{|c|c|c|c|}
\hline No. & States & $\begin{array}{c}\text { No. of } \\
\text { Historical } \\
\text { Buildings }\end{array}$ & $\begin{array}{c}\text { Percentage of } \\
\text { Historical } \\
\text { Buildings }\end{array}$ \\
\hline 1 & Penang & 5057 & $24.30 \%$ \\
\hline 2 & Perak & 3351 & $16.10 \%$ \\
\hline 3 & Johore & 2323 & $11.20 \%$ \\
\hline 4 & Malacca & 2177 & $10.50 \%$ \\
\hline 5 & Kuala Lumpur & 1763 & $8.40 \%$ \\
\hline 6 & Kedah & 1282 & $6.12 \%$ \\
\hline 7 & Selangor & 1166 & $5.60 \%$ \\
\hline 8 & Sarawak & 1010 & $4.90 \%$ \\
\hline 9 & Negeri Sembilan & 999 & $4.80 \%$ \\
\hline 10 & Pahang & 831 & $4.00 \%$ \\
\hline 11 & Terengganu & 420 & $2.00 \%$ \\
\hline 12 & Kelantan & 373 & $1.80 \%$ \\
\hline 13 & Perlis & 25 & $0.10 \%$ \\
\hline 14 & Sabah & 10 & $0.05 \%$ \\
\hline & Total & 20787 & $100 \%$ \\
\hline & & Source: Idid $(2005)$ & \\
\hline
\end{tabular}

In fact, Kamarul et al. (2008) examine that heritage buildings are an important element in town development which can be seen in some cities in the world. For example, the heritage buildings in Rome and London have become the main tourist attraction of each country. The buildings play an important role in defining the landmark within the urban area as well as generating income and boosting the tourism industry.

\subsubsection{Formatting author names and author affiliations}

Author names should be typed in 9-point Arial. The style for the names is First Names then Last Name, with a comma after all but the last two names, which are separated by "and". Do not use academic titles.

Affiliations of authors should be typed in italic 8point Arial. They should be preceded by a numerical superscript corresponding to the same superscript after the name of the author concerned. Please ensure that affiliations are as full and complete as possible and include the country.

\subsection{Defects in Heritage Buildings}

There are several types of defects that usually occur in the heritage buildings. Based on the literature review, the types of defects can be determined and grouped by the elements. Usually, the elements involved are external wall, internal wall, column, door, window, roof, ceiling, floor, and others (see figure 1). 


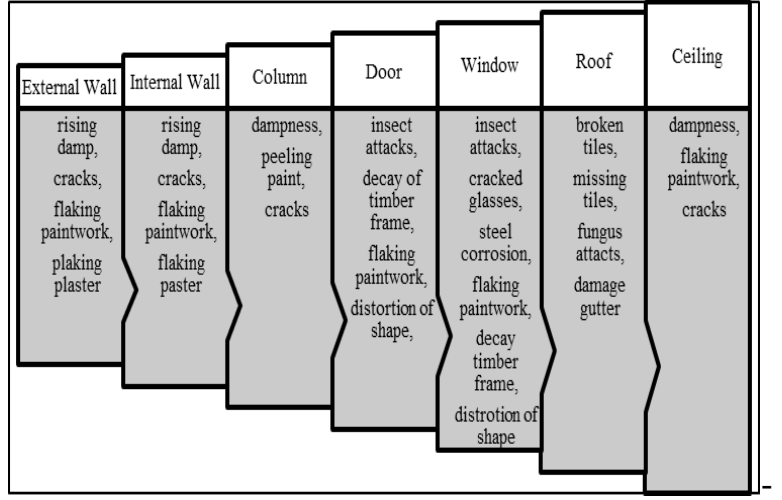

Figure 1. Types of Defects grouped by building elements

The major defect that usually occurs in the heritage buildings is on the external wall. Usually, the external wall is more exposed to defects because it is the outermost layer of the building and external wall also acts as the protection of the building. Kamarul et al. (2007) express that the common defects usually found on the external wall of heritage buildings are rising damp, cracking of brick, crumbling of mortar, flaking of the paintwork, and salt attack. Besides, other defects at the external wall are defective plastered renderings, and cracking of walls and leaning walls (Abdul Ghafar, 2004).

For the internal wall element of the heritage buildings, the defects that can be found are rising damp, cracking of brick, loose of plaster, discolour of paintwork, and cracking of tiles (Kamarul et al., 2007). Meanwhile, Mardziah and Md Azree (2012) discover the most common defects on this element are the effect of chemical actions inside the brick and plasters that appeared on the internal wall. Abdul Ghafar (2004) reports that the dampness penetration through walls also becomes a serious defect. It can occur at the external wall either internal wall, particularly in buildings located near water sources. In addition, Abdul Ghaffar (2004) also affirms that water penetration occurs commonly through walls exposed to prevailing wet wind or rain meanwhile dampness occurs in walls due to other factors such as leaking gutters or downpipes, defective drains, burst plumbing, and condensation due to inadequate ventilation.

Studies of heritage buildings in Malaysia by Abdul Ghaffar (2004) have highlighted that peeling paint is a common defect that happen in the column. Peeling paint usually occurs on building facades, mainly the columns and other areas that are exposed to excessive rain and dampness. The amount of the constant wind, rain, and sun received can easily turn the surface of the paint to become chalky and wrinkled or blistered.

The defects that normally appear at the door of the heritage buildings are decaying of timber frame, insect attacks, shape distortion, panel delamination, and paint flaking (Kamarul et al., 2007).

Based on the survey done by Po (2001), the defect occurs is the aluminum strips that can drop off window frame when it is not nailed securely. Kamarul et al (2007) also highlights that the decay of timber frame, insect attacks, flaking of paintwork, rushing of steel, and crack of glass are the general defects that commonly exist at the windows of heritage buildings.

Siti and Md Azree (2013) identify that there are several defects that occur at the roof element in heritage buildings. The most common defect that occurs at the roof are broken and missing roof tiles. Roof tiles may be missing and broken due to heavy rains. Second defect is damaged gutter. The possible reason of the damaged gutter is due to the overflow water caused by the heavy rain. Next, the fungal stains appeared on the roof tiles and roof parapets which come from the water. The fungal and mold appeared on the roof tiles and parapet because of the high pressure of water. This defect can be determined by the changes of original color and the appearance of the building element. The other defect in the roof of heritage buildings is timber decay. The timber becomes decay due to the moisture of water. For example, rain. Besides, another reason is weather conditions such as sun and rain that make the timber weak. Studies from Kamarul et al. (2007) prove that defects in the roof are usually sagging of timber frame, broken tiles, missing tiles, deterioration of the surface, and harmful growths. Besides, Mardziah and Md Azree (2012) point out the defect of the Heritage Shop house in Penang which is damp patches due to roof leakage. These patches can be easily seen in the building. Abdul Ghafar (2004) also points out some roof defects in the heritage buildings in Malaysia including corrosion of nails that fix the tiles at battens and rafters, the decay of battens, and the cracking of tiles caused by harmful growths. Harmful growths pose a danger to the tiles because it may lift tiles and create leaks. Moreover, Md Azree et al. (2014) state that there are different types of roof covering materials used in every school, such as asbestos, zinc sheets, and roof tiles. From some inspections, the roof defects found are blocked gutters, leaking downpipes, leaking roofs, missing roof tiles, slipping roof tiles, defective soffit, and fascia board.

Mardziah and Md Azree (2012) claim that the ceiling defect found at a Heritage Shop house in Penang is water staining. It was caused by the absence by the ineffectiveness of DPM in the floor upstairs. Moreover, the defects that usually take place on the ceiling of heritage buildings are watermarked, loose of plaster, and lichen of surfaces (Kamarul et al., 2007).

Damp of surface, cracking of screeds, loose of tiles, defective of floorboards, and decay of timber frame are the main types of defects that occur on the floor of the heritage buildings (Kamarul et al., 2007). In addition, Mardziah and Md Azree (2012) have listed the floor defects found at the Heritage Shop house in Penang; termite attacks and timber decay. These defects commonly occur on the internal floor.The use of sections to divide the text of the paper is optional and left as a decision for the author. Where the author wishes to divide the paper into sections the formatting shown in Table 2 should be used.

\section{Research Methodology}

To further investigate the types of defects based on building elements in school aged over 100 years in Perak, 
this study adopted observation method for data collection. For the observation, the data were collected in four (4) heritage school (see Table 2).

Table 2. The list of school buildings aged over 100 years in Perak .

\begin{tabular}{|l|c|}
\hline \multicolumn{1}{|c|}{ SCHOOL } & YEAR \\
\hline Clifford School, Kuala Kangsar & 1897 \\
\hline Sekolah Menengah Kebangsaan Sultan Yussuf, Batu Gajah & 1910 \\
\hline Anderson School, Ipoh & 1909 \\
\hline Convent School, Ipoh & $\mid 1907$ \\
\hline
\end{tabular}

The descriptive analysis is used to analyze and describe the observed data from four schools. Table 3 described the background of the four heritage schools. All four heritage schools were selected based on the history of Malaysia; Perak is one of the states that was under the British rule before independence. Thus, there were many schools built for British officers' children, King's children and much more.

Table 3. The background of school aged 100 years in Perak

\begin{tabular}{|c|c|}
\hline Background of school & Photos \\
\hline $\begin{array}{l}\text { The Clifford School, Kuala Kangsar is } \\
\text { originated from the Malay School, which } \\
\text { was founded in December 1897. In } 1897 \\
\text { appeared "Government English School" } \\
\text { and also known as "Hogan School" } \\
\text { named after the first headmaster, Mr } \\
\text { James Percival Charles Hogan. In 1928, } \\
\text { the school was renamed as "Clifford } \\
\text { School" as an appreciation to the } \\
\text { Governor of the Straits Settlements and } \\
\text { High Commissioner of Malaya at that } \\
\text { moment, Sir Hugh Clifford. During } \\
\text { World War II, the school changed its } \\
\text { status to a Japanese military headquarters } \\
\text { until } 1946 \text {. At the age of 100, the Clifford } \\
\text { School has been selected as one of the } \\
\text { pioneer schools; "Smart School". }\end{array}$ & $\begin{array}{c}\text { CLIFFORD } \\
\text { SCHOOL, } \\
\text { KUALA } \\
\text { KANGSAR }\end{array}$ \\
\hline $\begin{array}{l}\text { Sekolah Menengah Kebangsaan Sultan } \\
\text { Yussuf was found by En. K. } \\
\text { Malaiperumal in } 1907 \text {. This school can be } \\
\text { divided into three phases which are at the } \\
\text { first stage starting from } 1907-1910 \text {. } \\
\text { Then, the second phase is from } 1910 \text { to } \\
1951 \text { (41 years) when the school was } \\
\text { known as the Government Bahasa } \\
\text { Inggeris School. On October 15, } 1951 \text { the } \\
\text { school name was changed to Sultan } \\
\text { Yussuf School (SYS); named after the } \\
\text { Sultan of Perak at that time. The name } \\
\text { somehow remains until now. Besides, } \\
\text { Sekolah Menengah Kebangsaan Sultan } \\
\text { Yussuf also become the first English } \\
\text { school in Batu Gajah. The greatest } \\
\text { achievement of this school is the main } \\
\text { school building was gazetted as a national } \\
\text { heritage building because it was over } 100 \\
\text { years old. }\end{array}$ & $\begin{array}{c}\text { SEKOLAH } \\
\text { MENENGAH } \\
\text { KEBANGSAAN } \\
\text { SULTAN } \\
\text { YUSSUF }\end{array}$ \\
\hline
\end{tabular}

The Anderson High School was officially opened on 6th of February 1909. The name "Anderson" was taken from the name of the British High Commissioner in Malaya at that time, Sir John Anderson. Due to the lack of facilities at the Kuala Kangsar Malay College and reluctance of many Malay parents to send their children to missionary schools in Ipoh like the Anglo-Chinese School, the $\$ 45,000$ Anderson School building on Douglas Road was then built. Initially, the impressive building designed by A $\mathrm{R}$ Hubback only had ten classrooms and a large hall on the first floor. After 44 months of break during the Japanese Occupation, the school reopened its doors on the 24th of September 1945. The Anderson School is one of the schools that aged over 100 years and still in use until now.

The Convent School is an all-girls secondary school located at Jalan Sultan Idris Shah, Ipoh, Perak. The Convent School was established in 1907 and it is one of the oldest schools in Ipoh and is widely known as Main Convent Ipoh. The existence of the school itself was threatened by the primary school and was evacuated to the compound of SK Raja Perempuan in January 1994 when piling works for the construction of the Ipoh Parade, which was nearby, caused cracks to the school buildings. Besides, the original school building is now designated as a heritage site. The Convent School was 100 years old on 7 January 2007.

\section{Observation Analysis Findings}

This section describes about the types of defects in the school buildings aged over 100 years old. In this section, the types of defects are categorized based on elements which are external wall, roof, door, ceiling, staircase, column, internal wall, floor, and window and its details are shown in Table 4. All the types of defects occurred were identified from the observations done in four (4) different schools in Perak in three different locations via defects checklist.

Table 4. Types of defects in school buildings aged over 100 years

\begin{tabular}{|l|l|c|c|c|c|}
\hline Elements & \multicolumn{1}{|c|}{ Defects } & CONVENT & SYS & ANDERSON & CLIFFORD \\
\hline $\begin{array}{l}\text { External } \\
\text { Wall }\end{array}$ & Rising Damp & $/$ & $/$ & $\mathbf{X}$ & $/$ \\
\hline & Cracks & $/$ & $/$ & $/$ & $/$ \\
\hline & $\begin{array}{l}\text { Flaking } \\
\text { Paintwork }\end{array}$ & $/$ & $/$ & $/$ & $/$ \\
\hline & $\begin{array}{l}\text { Flaking } \\
\text { Plaster }\end{array}$ & $\mathbf{X}$ & $/$ & $/$ & $/$ \\
\hline
\end{tabular}




\begin{tabular}{|c|c|c|c|c|c|}
\hline Roof & Broken Tiles & 1 & 1 & $\mathbf{X}$ & 1 \\
\hline & Missing Tiles & 1 & 1 & 1 & $\mathbf{X}$ \\
\hline & $\begin{array}{l}\text { Fungus } \\
\text { Attacks }\end{array}$ & 1 & 1 & 1 & 1 \\
\hline & $\begin{array}{l}\text { Damage } \\
\text { Gutter }\end{array}$ & $\mathbf{x}$ & $\mathbf{x}$ & $\mathbf{x}$ & $\mathbf{x}$ \\
\hline \multirow[t]{4}{*}{ Door } & Insect Attacts & $\mathbf{X}$ & $\mathbf{X}$ & $\mathbf{X}$ & $\mathbf{X}$ \\
\hline & $\begin{array}{l}\text { Decay of } \\
\text { Timber Frame }\end{array}$ & $\mathbf{X}$ & $\mathbf{X}$ & $\mathbf{X}$ & $\mathbf{x}$ \\
\hline & $\begin{array}{l}\text { Flaking } \\
\text { Paintwork }\end{array}$ & $\mathbf{x}$ & 1 & $\mathbf{X}$ & 1 \\
\hline & $\begin{array}{l}\text { Distortion of } \\
\text { Shape }\end{array}$ & 1 & 1 & 1 & 1 \\
\hline \multirow[t]{3}{*}{ Ceiling } & Dampness & 1 & 1 & 1 & 1 \\
\hline & $\begin{array}{l}\text { Flaking } \\
\text { Paintwork }\end{array}$ & $\mathbf{x}$ & 1 & $\mathbf{x}$ & $\mathbf{x}$ \\
\hline & Cracks & $\mathbf{X}$ & $\mathbf{X}$ & 1 & $\mathbf{X}$ \\
\hline \multirow[t]{3}{*}{ Column } & Dampness & $\mathbf{X}$ & $\mathbf{X}$ & 1 & $\mathbf{X}$ \\
\hline & Peeling Paint & 1 & 1 & 1 & 1 \\
\hline & Cracks & 1 & 1 & 1 & 1 \\
\hline \multirow{4}{*}{$\begin{array}{l}\text { Internal } \\
\text { Wall }\end{array}$} & Rising Damp & 1 & 1 & 1 & $\mathbf{X}$ \\
\hline & Cracks & 1 & 1 & 1 & 1 \\
\hline & $\begin{array}{l}\text { Flaking } \\
\text { Paintwork }\end{array}$ & 1 & 1 & 1 & 1 \\
\hline & $\begin{array}{l}\text { Flaking } \\
\text { Plaster }\end{array}$ & $\mathbf{X}$ & $\mathbf{x}$ & 1 & 1 \\
\hline \multirow[t]{5}{*}{ Floor } & Dampness & $\mathbf{X}$ & $\mathbf{X}$ & $\mathbf{X}$ & $\mathbf{X}$ \\
\hline & Cracks & 1 & 1 & 1 & 1 \\
\hline & Timber Decay & $\mathbf{X}$ & $\mathbf{X}$ & $\mathbf{x}$ & $\mathbf{X}$ \\
\hline & Fungus & $\mathbf{X}$ & $\mathbf{x}$ & $\mathbf{X}$ & $\mathbf{X}$ \\
\hline & Mould Attacks & $\mathbf{x}$ & $\mathbf{x}$ & $\mathbf{x}$ & $\mathbf{X}$ \\
\hline \multirow[t]{6}{*}{ Window } & Insect Attacks & $\mathbf{X}$ & $\mathbf{X}$ & $\mathbf{X}$ & $\mathbf{N A}$ \\
\hline & $\begin{array}{l}\text { Cracked } \\
\text { Glassess }\end{array}$ & 1 & 1 & 1 & NA \\
\hline & $\begin{array}{l}\text { Steel } \\
\text { Corrosion }\end{array}$ & 1 & $\mathbf{x}$ & $\mathbf{x}$ & $\mathrm{NA}$ \\
\hline & $\begin{array}{l}\text { Flaking } \\
\text { Paintwork }\end{array}$ & I & 1 & $\mathbf{X}$ & $\mathbf{N A}$ \\
\hline & $\begin{array}{l}\text { Decay } \\
\text { Timberframe }\end{array}$ & 1 & 1 & 1 & NA \\
\hline & $\begin{array}{l}\text { Distrortion of } \\
\text { Shape }\end{array}$ & 1 & 1 & 1 & $\mathrm{NA}$ \\
\hline
\end{tabular}

\subsection{External Wall}

Based on the observations done at the Convent School, Ipoh, the common types of defects that usually occurred in the external wall were rising damp, cracks and flaking paintwork. Meanwhile, at SYS, the external wall of the school buildings was exposed to rising damp, cracks, flaking paintwork, and flaking plaster. It was quite different with the Anderson School because the rising damp did not occur in the external wall of the buildings, but it was still exposed to other defects such as cracks, flaking paintwork, and flaking plaster. Besides, the types of defects at the external wall of the Clifford School were the same as SYS; rising damp, cracks, flaking paintwork, and flaking plaster. Pictures in Table 5 shows the defects occurred in the external wall of the schools.

Table 5. Evidence of types of defects related to external wall

\begin{tabular}{|c|c|c|c|}
\hline $\begin{array}{l}\text { Convent } \\
\text { School }\end{array}$ & $\begin{array}{l}\text { SYS } \\
\text { SCHOOL }\end{array}$ & $\begin{array}{l}\text { CLIFFORD } \\
\text { SCHOOL }\end{array}$ & $\begin{array}{l}\text { ANDERSON } \\
\text { SCHOOL }\end{array}$ \\
\hline $\begin{array}{l}\text { Flaking } \\
\text { Paintwork }\end{array}$ & Wall Cracks & Rising Damp & 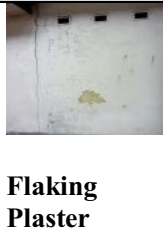 \\
\hline
\end{tabular}

\subsection{Roof}

The most common defects that occurred on the roof of the Convent School were broken tiles, missing tiles, and fungus attacks. Besides, SYS also faced the same types of defects in its roof. Meanwhile, for the Anderson School, the defects occurred on the roof were broken tiles, and fungus attacks only. Like the Anderson School, the Clifford School also had similar types of defects which were broken tiles, and fungus attacks. These defects mostly occurred in the main building of the schools. Pictures in Table 6 shows the defects occurred on the roof of the schools.

Table 6. Evidence of types of defects related to the roof

\begin{tabular}{|l|l|l|l|}
\hline $\begin{array}{l}\text { Convent } \\
\text { School }\end{array}$ & SYS SCHOOL & $\begin{array}{l}\text { CLIFFORD } \\
\text { SCHOOL }\end{array}$ & $\begin{array}{l}\text { ANDERSON } \\
\text { SCHOOL }\end{array}$ \\
\hline & & & \\
\hline $\begin{array}{l}\text { Broken } \\
\text { Roof } \\
\text { Covering }\end{array}$ & $\begin{array}{l}\text { Fungus } \\
\text { Attacks }\end{array}$ & Fungus Attack & Missing Tiles \\
\hline
\end{tabular}

\subsection{Door}

Based on the observations done at the Convent School and the Anderson School, there was only one type of defect that had been identified; distortion of shape. 
Besides, for SYS and the Clifford School, the types of defects occurred at the door were flaking paintwork and distortion of shape. Pictures in Table 7 show the defects occurred at the door of the schools.

Table 7. Evidence of types of defects related to door

\begin{tabular}{|l|l|l|l|}
\hline $\begin{array}{l}\text { Convent } \\
\text { School }\end{array}$ & SYS SCHOOL & $\begin{array}{l}\text { CLIFFORD } \\
\text { SCHOOL }\end{array}$ & $\begin{array}{l}\text { ANDERSON } \\
\text { SCHOOL }\end{array}$ \\
\hline & & & \\
\hline & & & \\
\hline $\begin{array}{l}\text { Distortion of } \\
\text { shape }\end{array}$ & $\begin{array}{l}\text { Flaking } \\
\text { Paintworks }\end{array}$ & $\begin{array}{l}\text { Flaking } \\
\text { Paintworks }\end{array}$ & $\begin{array}{l}\text { Distortion of } \\
\text { shape }\end{array}$ \\
\hline
\end{tabular}

\subsection{Ceiling}

The common ceiling defects that occurred in most of the buildings are damped, flaking paintwork, and cracks. Based on the observations made at the Convent School and the Clifford School, the dampness was the only defect occurred in their buildings. Meanwhile, the defects in buildings of SYS were dampness and flaking paintwork. The Anderson School had the same defects as the other schools, but it also had cracks in the ceiling. Pictures in Table 8 show the defects occurred at the door of the schools.

Table 8. Evidence of types of defects related to ceiling

\begin{tabular}{|l|l|l|l|}
\hline $\begin{array}{l}\text { Convent } \\
\text { School }\end{array}$ & $\begin{array}{l}\text { SYS } \\
\text { SCHOOL }\end{array}$ & $\begin{array}{l}\text { CLIFFORD } \\
\text { SCHOOL }\end{array}$ & $\begin{array}{l}\text { ANDERSON } \\
\text { SCHOOL }\end{array}$ \\
\hline & & & \\
\hline
\end{tabular}

\subsection{Column}

Mostly, the column defects occurred at the Convent School, SYS, and the Clifford School were peeling paint and cracks. At the Anderson School on the other hand, the column defects appeared were dampness, peeling paint, and cracks. These types of defects usually occur at the main column of the school buildings and it gives an awful image of the school. Pictures in Table 9 show the defects occurred at the column of the schools..

Table 9. Evidence of types of defects related to column

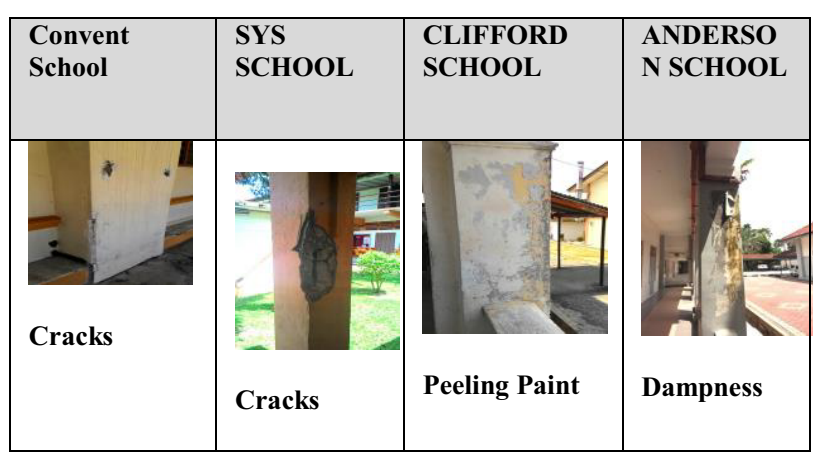

\subsection{Internal Wall}

Based on observations, the defects that could be identified in the internal wall of the Convent School and SYS were rising damp, cracks, and flaking paintwork. Besides, few of the listed defects occurred at the Anderson School include rising damp, cracks, flaking paintwork, and flaking plaster. At the Clifford School, it experienced different defects compared to the rest of the other schools because it did not have the rising damp defect. The defects occurred were cracks, flaking paintwork, and flaking plaster. Pictures in Table 10 show the defects occurred at the internal walls of the schools.

Table 10. Evidence of types of defects related to internal wall

\begin{tabular}{|l|l|l|l|}
\hline $\begin{array}{l}\text { Convent } \\
\text { School }\end{array}$ & $\begin{array}{l}\text { SYS } \\
\text { SCHOOL }\end{array}$ & $\begin{array}{l}\text { CLIFFORD } \\
\text { SCHOOL }\end{array}$ & $\begin{array}{l}\text { ANDERSO } \\
\text { N SCHOOL }\end{array}$ \\
\hline & & & \\
\hline & Cracks & $\begin{array}{l}\text { Flaking } \\
\text { Paintworks }\end{array}$ & Dampness \\
\hline
\end{tabular}

\subsection{Floors}

Since the entire floor in the Convent School, SYS, the Anderson School, and the Clifford School were made of cement, they shared the same defect which was cracked. This defect clearly appeared at the main entrance of the school buildings and the class path. Pictures in Table 11 shows the defects occurred at the floors of the schools.

Table 11. Evidence of types of defects related to floors

\begin{tabular}{|l|l|l|l|}
\hline $\begin{array}{l}\text { Convent } \\
\text { School }\end{array}$ & $\begin{array}{l}\text { SYS } \\
\text { SCHOOL }\end{array}$ & $\begin{array}{l}\text { CLIFFORD } \\
\text { SCHOOL }\end{array}$ & $\begin{array}{l}\text { ANDERSO } \\
\text { N SCHOOL }\end{array}$ \\
\hline & & & \\
& & & \\
\hline Cracks & & & \\
& Cracks & Cracks & Cracks \\
\hline
\end{tabular}




\subsection{Windows}

From the observations done, there were many defects found on the window of the Convent School, which were cracked glasses, steel corrosion, flaking paintwork, decayed timber frame, and distortion of shape. There was only one defect that was not found in this school, which was an insect attacks. Next, SYS experienced the same defects as the Convent School except for the steel corrosion that did not exist. Meanwhile, in the Anderson School, the types of defects found were cracked glasses, decayed timber frame, and distortion of shape. However, insect attacks, steel corrosion, and flaking paintwork were not discovered. Lastly, there was no defect found at the Clifford School due to its design. Pictures in Table 12 show the defects occurred at the windows of the schools.

Table 12. Evidence of types of defects related to windows

\begin{tabular}{|l|l|l|l|}
\hline $\begin{array}{l}\text { Convent } \\
\text { School }\end{array}$ & $\begin{array}{l}\text { SYS } \\
\text { SCHOOL }\end{array}$ & $\begin{array}{l}\text { CLIFFORD } \\
\text { SCHOOL }\end{array}$ & $\begin{array}{l}\text { ANDERSON } \\
\text { SCHOOL }\end{array}$ \\
\hline $\begin{array}{l}\text { SCHape } \\
\text { Shaton of } \\
\text { Shape }\end{array}$ & No defect & \\
\hline
\end{tabular}

\subsection{Discussion}

The objective of this research is to identify the types of defect at the school building over 100 years old through observation. In this research, there are four (4) schools in Perak that are over 100 years old of age selected, which are Convent School, Anderson School, Clifford School and Sekolah Menengah Kebangsaan Sultan Yussuf. From the previous research, there are lots of types of defects that exist in a heritage building and some researchers categorized them based on elements and specify the defects in general only (Kamarul et. al.,2007; Mardziah and Md Azree 2012; Siti and Md Azree, 2013; Md Azree et. al, 2014). The examples of defect at heritage buildings are cracking of walls, flaking plaster and paintworks at walls, dampness at the ceiling, cracking of column, fungus attack on the roof, distortion of shape on window and door and others. Based on the observation done on the four (4) school buildings over 100 years in Perak, it is found that the school buildings expose the same defect problems with other buildings over 100 years. The elements that affected towards defect at all the four (4) school buildings are external wall, internal wall, roof, ceiling, floor, staircase, column, door and window. As conclusion, this study identifies that Clifford School is the one has less defects due to the appropriate design of the building.

\section{Conclusion}

In conclusion, all of the objectives of this research have been achieved successfully. Based on the research, it is shown that the types of defects that usually occur in school buildings over 100 years in Perak are quite similar to other heritage buildings in Malaysia. The longer the age of the particular building is, the more defects appear.

\section{References}

1. A.Ghafar,A, The Dilapidation Survey Report. ,"Majalah Akitek", V.16, I.1, 19-21 (2004)

2. A.Ghaffar,A. British Colonial Architecture in Malaysia 1800-1930. KL: Jab Muzium Malaysia. (1997)

3. Abdullah, A,B. Billions wasted in repairing buildings. NAFAM Conf KL, 13-14 August (2007).

4. Arazi.I, Faris.K and Mahmoud.S, Maintenance Management Framework for Conservation of Heritage Buildings in Malaysia. JMAS. Vol. 4, No. 11,66-77 (2010).

5. Chew, M., Y., L. Defect analysis in wet areas of buildings. JCBM,165-173. (2004).

6. Haryati M.I, Learning from Defects in Design and Build Hospital Projects in Malaysia. Int Conf on SocSci \&Humanity, Vol 5, 238-242 92 (2011)

7. Idid, S.Z.A. Pemeliharaan Warisan Rupa Bandar: Panduan Mengenali Warisan Rupa Bandar Berasaskan Inventori Bangunan Warisan Malaysia. KL:BWM. (1995)

8. Kamarul S.K, Lilawati A.W and A.Ghafar.A. Pilot Survey on The Conservation Of Historical Buildings In Malaysia. Proc of 2nd. Int conf on BEDC,3-4th. USM (2008).

9. Kamarul S.K, Lilawati A.W, A.Ghafar.A and Saipol Bari A.K). Understanding the common Building Defect in Malaysia's Historic Buildings, The Int Conf on BEDC, 3rd-4th, USM (2007)

10. Mardziah K. and Md. Azree O.M. Building Condition Assessment And Defect Analysis On Heritage Shophouse In Peneng, Malaysia: Case Study. IJE. Vol. 2(3), 77-80, (2012)

11. Md Azree O.M, N.A. Agus Salim, S.W. Tan, N.M. Tawil and N. Md Ulang Assessment of Significant Causes to School Building Defects. (2014).

12. Nadia O. and Md Azree O.M (2013). General Building Defects: Causes, Symptoms and Remedial Work. EJTD, Vol.(3), No 1 (2014)

13. Nielsen, J., Hansen, E. J. D. E., and Aagard, N. Buildability as Tool for Optimisation of Building Defects. SS, Vol 8, pp25-32. (2006).

14. Olanrewaju, A. L., Mohd Faris, K., and Arazi, I. Sustainability in the Context of Maintenance: Building Defects in the Malaysian University Campus. (2010).

15. Pheng, L.S. and Wee, DImproving maintenance and reducing building defects through ISO 9000. JQME, Vol 7 No 1, 6-24 . (2001). 
16. Po Seng Kian (2001) A Review Of Factors Affecting Building Defects In Singapore. DTl, Vol. 3, No. 2, 64-68 (2001)

17. Shittu, A. A., Adamu, A. D., Mohamed, A., Suleiman, B., Isa, R. B., Ibrahim, K., and Shehu, M. A. Appraisal of Building Defects Due To Poor Workmanship in Public Building in Minna, Nigeria. JE, Vol 3, 30-38. 95 (2013).

18. Siti Solehah M.S and Md Azree O.M Heritage Building Roof Element Conservation: Peneng Old Town Hall Case Study, JER. Vol. 42, No.2, 424. (2013).

19. Suhana J., Adi Irfan C.A, Norngaini M.T., Surat, M. and Kamaruzzaman, S.N. Preliminary Survey and Defect Analysis of Traditional Timber Mosques in Malaysia. (2013).

20. Zainal A.A, Sharifah Haminah S., Ismail, Abdul Rahman and Maizam A. SchBldMaintenance Strategy: A New Management Approach. Reservation; MUCEET, (2009). 